This item was submitted to Loughborough's Research Repository by the author.

Items in Figshare are protected by copyright, with all rights reserved, unless otherwise indicated.

\title{
Can cooperative learning achieve the four learning outcomes of physical education? A review of literature
}

PLEASE CITE THE PUBLISHED VERSION

http://dx.doi.org/10.1080/00336297.2014.984733

\section{PUBLISHER}

Taylor and Francis / @ National Association for Kinesiology in Higher Education (NAKHE)

\section{VERSION}

AM (Accepted Manuscript)

\section{PUBLISHER STATEMENT}

This work is made available according to the conditions of the Creative Commons Attribution-NonCommercialNoDerivatives 4.0 International (CC BY-NC-ND 4.0) licence. Full details of this licence are available at: https://creativecommons.org/licenses/by-nc-nd/4.0/

\section{LICENCE}

CC BY-NC-ND 4.0

\section{REPOSITORY RECORD}

Casey, Ashley, and Victoria A. Goodyear. 2019. "Can Cooperative Learning Achieve the Four Learning Outcomes of Physical Education? A Review of Literature”. figshare. https://hdl.handle.net/2134/19534. 
Can Cooperative Learning achieve the four learning outcomes of physical education?: A Review of Literature

\section{Abstract (150 words)}

Physical, cognitive, social, and affective learning are positioned as the legitimate learning outcomes of physical education It has been argued that these four learning outcomes go some way to facilitating students’ engagement with the physically active life (Bailey et al., 2009; Kirk, 2013). With Cooperative Learning positioned as a pedagogical model capable of supporting these four learning outcomes (Dyson \& Casey, 2012), the purpose of this review was to explore 'how has the empirical research in the use of Cooperative Learning in physical education reported on the achievement of learning in the physical, cognitive, social, and affective domains (or their equivalents)?’ The review found that while learning occurred in all four domains, the predominant outcomes were reported in the physical, cognitive, and social domains. Affective learning was reported anecdotally and it became clear that more work is required in this area. The paper concludes by suggesting that research into the outcomes of this, and other pedagogical models, needs to focus on learning beyond the initial unit and over a period of years and not just weeks.

Keywords: Peer-assisted learning, group work, competitive, individualistic learning 
Can Cooperative Learning achieve the four learning outcomes of physical education?: A Review of Literature

If physical education is to sustain its valued cultural and moral position within education, Kirk (2013) argued that we should focus on how best to promote the "educationally beneficial outcomes for students, across a range of domains” (p. 6). Drawing on Bailey et al.'s (2009) discussions on educationally beneficial learning outcomes in physical education, Kirk (2010, 2012, 2013), among others (c.f. Haerens, Kirk, Cardon, \& De Bourdeaudhuij, 2011; Metzler, 2011), has argued that we should comprehensively and cohesively address learning in the physical, cognitive, social and affective domains. Indeed, for physical education to be capable of promoting the physically active life, Kirk (2012) positioned these four learning domains as the legitimate learning outcomes of physical education. However, given that Bailey et al. (2009) felt that learning in these domains can only occur "given the right social, contextual and pedagogical circumstances” (p.16) how do we 'know' if legitimate learning is occurring?

One way in which the pedagogical circumstances, the legitimate learning outcomes of physical education, and a socio-cultural perspective to learning can be considered is through models (O’Sullivan, 2013), and more specifically pedagogical models (Kirk, 2013). There is an increasing level of advocacy for the use of pedagogical models, and at the forefront of this argument are Kirk (2012, 2013) and Metzler (2011). Kirk (2012) claims that for physical education to achieve cultural legitimacy in the medium ( $\sim 10$ years) and long term future $(\sim 20$ years) physical education should adopt a models-based approach. In other words, curricula should be organized around pedagogical models rather than the multi-activity approach.

Pedagogical models, nor curriculum or instructional models as Jewett and Bain (1985) and Metzler (2011) have respectively called them, are not new but some have received more attention than others. Certainly, while models including Sport Education and Teaching 
Games for Understanding were constructed and developed in the 1980s by researchers in the field of physical education and sport pedagogy, Cooperative Learning only began to gain momentum in physical education during the early part of the 21st Century and emerged from its use in other curriculum subjects such as English, Math, and Science (Dyson \& Casey, 2012; Johnson \& Johnson, 2009). Such has been the enduring presence of Sport Education and Teaching Games for Understanding that both have been the subjects of review of literatures of their own (for the two latest examples see: Harvey \& Jarrett, 2013; Hastie, de Ojeda, \& Lucquin, 2011). In contrast, Cooperative Learning has hitherto been clustered with Peer-Assisted Learning (PAL) in any systematic reviews in this area (see Ward \& Lee, 2005). Given the emergence of Cooperative Learning as a legitimate pedagogical model in physical education (Dyson \& Casey, 2012; Metzler 2011) it seems appropriate, at this time, to review the developing body of literature published in this area; especially if we are to better understand if the model is capable of facilitating learning in the four domains positioned by Kirk (2012) as the legitimate learning outcomes of physical education.

\section{Cooperative Learning as a pedagogical model}

Cooperative Learning was developed in the 1970s amidst concerns that students rarely had the opportunity to develop or even use their interpersonal skills in the traditional competitive and individual learning environments (Johnson \& Johnson, 2009; Kagan \& Kagan, 2009; Slavin, 1995, 1996). Through combining social and academic learning, Cooperative Learning was seen as a method of promoting students' interpersonal skills and their ability to interact and achieve in an ever changing economic and social society (Kagan \& Kagan, 2009). Since its initial development Cooperative Learning has been researched extensively. The separate meta-analyses (Johnson, Maruyama, Johnson, \& Nelson, 1981; Johnson, Johnson, \& Stanne, 2000; Kyndt et al., 2013; Stanne, Johnson, \& Johnson, 1991), and the reviews of literature (Johnson \& Johnson, 1974; Slavin, 1983) suggest that 
Cooperative Learning brings about significant gains to students' learning and furthers their development as young people. Indeed, the reported learning outcomes of Cooperative Learning from these analyses and reviews can be summarized as academic achievement (an ability to apply and understand content), interpersonal skill development and relations (communication skills and/or peer relations), enhanced participation (engagement with learning tasks), and an improvement in young people’s psychological health (self-esteem and/or motivation).

These reported learning outcomes have great synergy with the aspired learning outcomes of physical education that were identified by Bailey et al. (2009) and later reenforced by Kirk (2013). Certainly, in his positioning of Cooperative Learning as a model of physical education, Metzler (2011) drew on the work of Hilke (1990) to argue that Cooperative Learning was an achievement-orientated and process-orientated model. In other words, and when applying the learning outcomes of Cooperative Learning to physical education, the model is designed to foster gains in physical performance and cognitive understanding (i.e. academic achievement), to happen in coherence with the development and use of students' interpersonal skills and their meaningful participation in learning (i.e. social learning), and to help students increased motivation, self-esteem or self-confidence to learn (i.e. affective learning) (Bailey et al., 2009; Casey \& Dyson, 2009; Hilke, 1990; Metzler, 2011). Taking this stance, and by drawing on the extensive empirical evidence in general education, Cooperative Learning is a model that could be said to effectively promote the achievement of student learning in the physical, cognitive, social and affective domains - at least in general education. The question that concerns this review of literature is can Cooperative Learning achieve these selfsame learning outcomes in physical education?

Since the early empirical work in physical education by Dyson and Strachan (2000), there has been an increase in the international breadth and scope of research in this area. 
Drawing on research from eight international countries, and the subsequent conclusions made from pedagogical research in the last decade, Casey and Dyson (2012) believed that Cooperative Learning considers human movement to be "something which is undertaken within a cooperative relationship with others” (p. 173). In contrast to traditional pedagogical practices, Cooperative Learning acknowledges that "teaching as telling is no longer appropriate” (Lieberman \& Pointer-Mace, 2008, p. 226) and that movement and learning about movement does not occur in isolation from the cognitive, social, or affective domains (Casey \& Dyson, 2012; Dyson, 2001; Lafont, Proeres, \& Vallet, 2007). Through Cooperative Learning young people learn about movement in physical activity contexts and understand how their experiences are relevant, meaningful, and transferable, by working together to learn without direct instruction from the teacher (Bähr \& Wilbowo, 2012). Students are encouraged to interact with each other and learn from the experiences that they create (Dyson, Griffin, \& Hastie, 2004).

Moving Metzler’s (2011) interpretation of Cooperative Learning forwards, Casey and Dyson (2012) recently positioned Cooperative Learning as a pedagogical model due to its ability to meet the legitimate learning outcomes of physical education by exploring the interrelation between teaching, learning, content, and context. Reinforcing Dyson and Grineski (2001) and Dyson and Rubin’s (2003) earlier arguments, Casey and Dyson (2012) considered learning in the physical, social, cognitive, and affective domains, and the interrelation of the four concepts of pedagogy, to occur as a result of teachers' use of five fundamental elements (positive interdependence, individual accountability, group processing, promotive face-to-face interaction and small group and interpersonal skills). While Cooperative Learning was developed along four separate lines in education by its protagonists Johnson and Johnson, Slavin, Kagan, and Cohen (who all hold differing perspectives as to what elements and structures support group work and enhance 
achievement) physical education has followed Johnson and Johnson’s (1991) conceptual approach where the five fundamental elements define group work (Goodyear, 2013). Perhaps influenced by Dyson's earlier application of the conceptual approach, these five elements have been positioned as a central pentagonal scaffold, which supports, facilitates, and deepens the achievement of the four learning outcomes (i.e. physical, social, cognitive, and affective) of physical education (Dowler, 2012; Dyson \& Strachan, 2000; Lafont, 2012). Despite the positioning of models (Kirk, 2013; O’Sullivan, 2013) as a central facet of the possible future of physical education and the publishing of a number of reviews on other models (Sport Education and Teaching Games for Understanding), Cooperative Learning has yet to be acknowledged as having anything but a beginning literature in physical education (Barrett, 2005). The only comparable review of its kind was conducted by Stanne, Johnson, and Johnson (2000) who, in exploring the effect of cooperative, competitive, and individualistic learning in kinesiology, suggested that Cooperative Learning brought about gains to students’ motor performance, social support, interpersonal attraction, and selfesteem. Yet in physical education there is no analysis of the literature that seeks to ascertain whether Cooperative Learning can bring about these learning outcomes and indeed fulfill the physical, cognitive, social, and affective learning outcomes of the subject.

In order to legitimize Cooperative Learning as a current and future pedagogical practice, we need to move beyond the notion that Cooperative Learning 'works' and start to think of the future directions for research in this area (Casey, 2014). Certainly we need a comprehensive understanding of if and how Cooperative Learning provides the right pedagogical circumstances for achieving the educational beneficial learning outcomes of physical education. In doing so, and as this review sets out to achieve, we can begin to ascertain the 'worthiness' of Cooperative Learning within a models-based approach and 
begin to conceptualize directions for future research that could enhance and strengthen teaching and learning in physical education.

\section{Methodology of review}

Shulruf (2010) held that the purpose of any systematic review of literature is to “examine the material pertaining to a particular area” (p. 596). The key difference between a systematic approach and a traditional descriptive or narrative review is that it uses methods that allow the researchers to control potential methodological biases (Shulruf, 2010). This approach acknowledges the body of research that exists and seeks to draw synthesis from the findings while acknowledging and accounting for researcher bias (Barr, Hammick, Koppel, \& Reeves, 1999: Boaz, Ashby, \& Young, 2002).

In seeking to undertake a systematic review of the empirical literature pertaining to the use of Cooperative Learning in physical education we chose to follow Shulruf's (2010) five methodological steps. In what follows we show how we adhered to these steps and the processes we undertook in completing this review

1. Focus on a specific question: "How has the empirical research in the use of Cooperative Learning in physical education reported on the achievement of learning in the physical, cognitive, social and affective domains (or their equivalents)?”

2. Use a protocol to guide and plan the processes to be followed: The basis of this paper is a consideration of peer-reviewed, empirical research into teachers', pre-service teachers', and K12 and higher education students' experiences of Cooperative Learning in physical education and physical activity contexts.

3. Identify as much of the relevant literature as possible through a comprehensive search: Papers were selected by searching EBSCO databases and the Physical Education Index with the main search term being “Cooperative Learning Physical Education”. Secondary searches were completed using the main search term "Cooperative Learning” as 
sub categories of "physical education”, “physical activity” and, “movement”. Physical activity and movement contexts were selected as related terms to further the scope of studies found that reported on Cooperative Learning in physical education but to also use physical activity and other movement related contexts to inform physical education literature. After this initial search papers were analyzed for suitability. Further journal articles were obtained through the citations and references in the originally discovered documents.

4. Make decisions about the inclusion and exclusion of studies based on methodological criteria: All potential papers were scanned to ensure they met the inclusion criteria. The only studies contained within the present review were empirically-based, interventional, peer-reviewed papers written in English. Purely descriptive papers or dissertation abstracts were not considered. In this way, even though some papers represented data they were excluded from the final review if they did not represent the intervention or discuss the methods of analysis. This included several peer-reviewed professional papers in journals such as Physical Education Matters. Furthermore, papers were also excluded if they reported on cooperative games rather than Cooperative Learning. Cooperative games do not necessitate the use of the five fundamental elements, but instead suggests that students should be dependent on one-another to learn (Dyson \& Grineski, 2001; Grineski, 1996). Thus, cooperative games are pedagogical practices that differ to the Cooperative Learning model. In the end twenty-seven papers were identified that satisfied the selection criteria.

5. Synthesis research findings and being explicit and transparent: Analysis of the twenty-seven papers followed a systematic process of inductive analysis and constant comparison (as per the protocols recommended by Denzin and Lincoln (1994) and Lincoln and Guba (1985)). We firstly read through each paper to confirm its initial inclusion in the review. Once this was done we independently read the paper again and coded the papers "to make the task of analysis more straightforward by sifting relevant material from a large body 
[of writing]” (Potter 2009, p. 615). These coded sections were transcribed and affixed with preliminary notes about their nature and interest. The selection of codes was inclusive at this stage. Coding then became a cyclical process and new understanding brought both of us back to previously read material with fresh understanding (Potter, 2009).

The initial codes and notes were 'cut and pasted' so that "all (or a subset of) the data on a given theme could be put together” (Lee \& Fielding, 2009, p. 537). We then compared the separate bodies of codes and either combined them and placed into wider unnamed categories (which were also given notes about their nature and interest) or discarded them. This process was more exclusive as material deemed irrelevant was discounted from the review. These categories (and their accompanying notes) remained fluid until such time the themes of this review were consolidated through the process of inductive analysis undertaken by the authors. Throughout, and to help manage bias and increase the trustworthiness of these findings, we made all key decisions together (Kitchenham, 2004).

The analysis of the twenty-seven papers revealed four key findings/themes pertaining to the physical, cognitive, social, and affective domains: (a) Academic Learning (this theme contains findings related to the physical and cognitive domains), (b) Social Learning, (c) Team Participation (both themes (b) and (c) related to findings around the social domain), and (d) Affective Learning (explores reported findings in the affective domain). Each of these themes will be discussed in relation to their respective learning domain(s) in the results section.

\section{Trends and Limitations}

Before discussing the results it is worth noting some common trends and some potential limitations with the studies undertaken to date on Cooperative Learning in physical education. The literature surrounding the development of student learning in physical, cognitive, social, and affective domains, while diverse (i.e. studies from nine countries 
feature in this review) seem to predominantly focus on work from the USA, the UK and France. Furthermore, this body of research mostly centers on answering the question "does it work” rather than asking what the benefits to learners and their learning might be over time.

In his consideration of the potential futures for physical education Kirk (2010), drawing on the work of Ennis (1999), held that any continuation of units of work lasting between four and six lessons (that is inherent within multi-activity curriculum) does not allow learning to progress beyond the elementary level. In other words, students are only introduced to new movement skills, tactics and techniques and are afforded limited time to become fluent in their movement capabilities. However, short lesson units remain particularly evident in pedagogical models, despite a growing body of research that suggests it takes multiple units for students to learn how to learn in this way (cf. Casey, 2014; Goodyear, 2013; Hastie et al., 2011; Harvey \& Jarrett, 2013). Indeed six papers in this review explored the use of Cooperative Learning across units lasting six lessons or less, while a further six studies explored learning within units of less than ten lessons. The emphasis on short studies is a limitation of both in this review and the wider research in Cooperative Learning. However, it also suggests that Cooperative Learning (like other pedagogical models - see for example Harvey and Jarrett's (2013) review of Games Centred Approaches) has often found a place to exist only within a wider multi-activity curriculum.

Given the reported importance of the five elements of Cooperative Learning (c.f. Dyson \& Casey, 2012; Johnson \& Johnson, 2009) it is surprising to note that only six of the twenty-seven papers made deliberate reference to how the five elements were actualized in the teaching of the units of work. However, while the majority of papers did not report on the five elements over half of the papers (17 out of 27) identified the structure that was implemented. Since Dyson and Grineski (2001) argued that Cooperative Learning structures support the fulfillment of the elements, by providing ways of organizing students for 
interaction, it could be argued that these papers at least sought to use the five elements. Nonetheless, and building on the work of [masked for peer review] and [masked for peer review], in the majority of papers the reader was left to accept the author(s) word that Cooperative Learning had been used. Moreover, twenty-one of the twenty-seven papers offered no explanation as to how the teacher(s) had maintained "curriculum fidelity" (Zhu, Ennis, \& Chen, 2011) with the model. In contrast all papers gave some details about the number, age, and prior experience of participants although the level of detail (especially around teacher(s) experiences of using Cooperative Learning varied from paper to paper.

The study by Dyson, Linehan, and Hastie (2010) stands out in this review as the exemplarily paper because of its diligence in presenting evidence to the reader in each of these categories. It provided explanations and details on the inclusion of the five elements and the structure used, it sought to show how fidelity with the model was maintained, it gave details of the participants and their prior experience, and the paper engaged with the model for an extended six-month period. Moving forwards beyond this review, this approach taken by Dyson et al. (2010) should serve as a potential yardstick for future studies on Cooperative Learning in physical education.

\section{Results}

The primary focus of the majority of school-based empirical research on the Cooperative Learning model in physical education has explored student learning (Cohen \& Zach, 2012). In different cultural contexts and settings (K12 and higher education), Cooperative Learning was reported to have an impact on students' physical competence, cognitive understanding, social skills, and their affective development (Goodyear \& Casey, 2013). Indeed, on a number of occasions the learning outcomes were interrelated, whereby academic and social learning were seen and positioned as being on a par with one-another (Casey, Dyson, \& Campbell, 2009). For example, Lafont (2012) suggested that as students' 
progressed their communication skills (social learning) so their understanding of the motor skills also improved (academic learning). Furthermore, and as a consequence of improved communication with each other, improvements in motor performance and the tactical choices were reported to have occurred. Additionally, students reported that their throwing and catching skills were enhanced due to heightened levels of confidence, enjoyment, and selfesteem, developed as a result of receiving feedback and encouragement from members of their team (Dyson, 2001).

The mechanisms used to make judgments about student learning varied between studies. Overall there was a balance between qualitative and quantitative data procedures, yet most judgments were made using qualitative methods (14 studies) rather than quantitative (11 studies) or mixed method designs (2 studies). Furthermore, it was only the quantitative studies that compared student learning to a control group (11 studies). Subsequently, over half of the judgments about student learning were not compared to other learners practicing in a different pedagogical approach to Cooperative Learning (16 studies).

One of the broadest, albeit anecdotal, findings of this review was that teachers believed that student learning progressed in each of the four domains. Furthermore, teachers believed that this learning surpassed that achieved in the traditional pedagogical approaches (i.e. skills and drills) used prior to using Cooperative Learning. However, as we explore the four themes: (a) Academic Learning, (b) Social Learning, (c) Team Participation, and (d) Affective Learning - it becomes clearer that empirical support for this anecdotal evidence ranges between the strong and the tenuous.

\section{Academic Learning}

In exploring this theme we aim to show how learning in the physical and cognitive domains has been reported. Primarily we suggest that academic learning has been positioned as either physical development (often in the form of skill and technique improvement) or 
cognitive development (often in the form of increased tactical understanding and/or improved decision making). Focusing on academic learning allows us to explore Cooperative Learning's reported ability to enhance learning in these two domains.

A central feature of physical learning was enhanced game performance and improvements to students’ motor skills. Quantitative (3 studies), Qualitative (4 studies) and, mixed method designs (2 studies) reported on the improvements made by students in this aspect of physical education (Barrett, 2005; Casey et al., 2009; Darnis \& Lafont, 2013; Dyson, 2002, 2001; Dyson et al., 2010; Dyson \& Strachan, 2000, 2004; Lafont et al., 2007). Specifically, the literature showed that the use of Cooperative Learning enhanced the intensity of game play and/or physical activity. Cooperative Learning created more opportunities for passing and shooting, enhanced students' use and understanding of complex tactics, and simply provided time for students to have more 'goes' at different activities. Moreover, students’ ability to accurately replicate skills, both in games and activities such as track and field athletics, was also enhanced. With regard to cognitive learning several studies showed that students had an enhanced game related understanding of strategies, skills, and the transfer of these to other activities (Casey, 2013; Casey \& Dyson, 2009; Dyson, 2002; Dyson et al., 2010; Dyson \& Strachan, 2004, 2000; Hastie \& Casey, 2010; O’Leary \& Griggs, 2010).

One of the core reasons for enhanced academic learning was identified as being the increased opportunities to talk. Discussions and the time for promotive face-to-face interaction afforded students the opportunity to problem solve and in engage in higher-order thinking (Casey, 2004; Darnis \& Lafont, 2013; Dyson \& Strachan, 2004; Gossett \& Fischer, 2005; Hastie \& Casey, 2010). Interactions become promotive of the learning outcomes and focused on the task rather than being mundane and focused on anything and everything but the task (Smith \& Parr, 2007). Darnis and Lafont (2013) summarized this key finding when 
they suggested that cooperative groups discussions about their strategies for games led to improved motor and tactical skills.

Therefore, this theme has shown that Cooperative Learning develops academic learning through the physical and cognitive learning domains. Students acquire a level of physical competence and develop an understanding of movement techniques and tactics as a consequence of engaging with Cooperative Learning; most specifically (but not exclusively) because of the time that was given to promotive face-to-face interaction.

\section{Social Learning}

In agreement with Casey et al.’s (2009) argument that Cooperative Learning places academic and social learning on an equal par, and Metzler's (2011) discussions around the achievement and process orientated nature of the model, social learning was frequently mentioned as a learning outcome. The outcomes that represented social learning included, (a) the development in interpersonal skills, (b) interpersonal relations and the ability to listen to team members, and (c) beliefs, the sharing of ideas, and constructing new understandings together (Casey, 2013; Casey et al., 2009; Casey \& Dyson, 2009; Dyson, 2001, 2002; Dyson \& Strachan, 2000, 2004; Goudas \& Magotsiou, 2009). Significantly, these were all reported to occur in conjunction with the gains in academic achievement. For example, developments in physical performance were frequently attributed to receiving feedback and encouragement from peers (Barratt, 2005; Casey, 2004; Dyson, 2001, 2002; Dyson et al., 2010; Goodyear, Casey \& Kirk, 2012).

However, social learning was not just about the ability to cooperate with one another, work together as a team to learn, or developing good social relations, although these were all evident in the findings (Andre, Louvet, \& Deneuve, 2011, 2013; Bayraktar, 2011; Casey, 2013; Casey et al., 2009; Casey \& Dyson, 2009; Dyson, 2001, 2002; Dyson \& Strachan, 2000, 2004; Goudas \& Magotsiou, 2009; Hastie \& Casey, 2010). Social Learning was also 


\section{COOPERATIVE LEARNING REVIEW OF LITERATURE}

about showing care, concern, empathy, and respect for each other, supporting and encouraging one another to learn (Bayraktar, 2011; Casey et al., 2009; Dyson, 2001, 2002; Dyson \& Strachan, 2000; Goudas \& Magotsiou, 2009; Johnson, Bjorkland, \& Krotee, 1984; Yoder, 1993). For example, Goudas and Magotsiou (2009) found that as students increased their cooperative skills and their empathy for their teammates students' quick temperedness and their tendency to disrupt decreased. Yet while the development in all of these social skills supported academic achievement these skills took time to develop. Although there is no definitive figure for this, with different students adapting at different speeds, Casey et al. (2009) suggested that it took the initial few lessons and the first few weeks of a unit before students were comfortable working in their groups and could begin cooperating with each other.

One of the reasons cited for students’ ability to cooperate and show empathy and respect for their teammates was the developing leadership skill set of the students (Darnis \& Lafont, 2013; Dyson, 2001; Dyson \& Strachan, 2000). Specifically enhanced leadership skills were seen through students' ability to guide their teams through a process of learning, their ability to take responsibility for their own and other individuals learning, enhanced communication skills, and in particular, the ability to listen and speak clearly (Casey, 2004; Darnis \& Lafont, 2013; Dyson, 2002, 2004; Dyson \& Strachan, 2000; O’Leary \& Griggs, 2010). O’Leary and Griggs (2010, p. 78) account of learners in a higher education setting provides an example of the developing leadership skill set of students:

Listening to others, accepting the beliefs of the home-group members and potentially developing ideas for the required sequence. Moreover, a number of students felt that the responsibility of listening to their peers developed their cognitive learning in terms of remembering what they had been taught and understanding the material better 
While social learning was most obviously reported in the interaction between students, much of what occurred was embedded in team interaction. However, given the prevalence of both Dyson and Grineski’s (2001) learning teams structure (it featured in eleven out of the twenty-seven studies) and Aronson, Blaney, Stephan, Sikes, and Snapp (1978) Jigsaw Classroom structure (featuring in four studies) coupled with the clear emphasis on games lessons (fourteen out of the twenty-seven studies used games as their context of choice), it is unsurprising to discover that team participation made up the majority of the reports about social learning.

\section{Team Participation}

Through the use of the Cooperative Learning structure learning teams (and the argument that Cooperative Learning structures support the fulfillment of the elements (Dyson \& Grineski, 2001)) it was foreseeable that a large number of the studies were reporting on the impact of some of the five elements on learning. Positive interdependence (often implemented through student roles inherent within learning teams (Dyson, 2001, 2002; Goodyear et al., 2012, 2013)) and individual accountability (often implemented through member signatures, peer feedback, constant monitoring and interactions by the teacher and tick sheets to record performance (Dyson et al., 2010)) both supported active participation. Engagement was supported, since students were required to take responsibility for team learning and organizing themselves as a team (Dyson, 2001, 2002; Dyson \& Strachan, 2000, 2004; Goodyear et al., 2012, 2013; O’Leary \& Griggs, 2010) becoming, as Hastie and Casey (2010, p. 18) suggested, "self managers”. Significantly, students saw themselves as more than just performers and felt that they had a wider responsibility to the group. Dyson and Strachan (2000) observed that "even during illness students participated in non-active roles, acting as coach for the day, coordinating the implementation and refinement of game strategy" (p. 28). 
As students became increasingly used to the Cooperative Learning environment, active participation was further developed. Students were on task for the majority of lesson time (Dyson et al., 2010; Dyson \& Strachan, 2004; Goudas \& Magotsiou, 2009; O’Leary \& Griggs, 2010) and became increasingly less dependent on the teacher and more dependent on each other. Subsequently, as units progressed students spent increasingly more time in learning tasks working together to learn without waiting for instructions from the teacher (Casey, 2013; Casey \& Dyson, 2009; Dyson, 2001, 2002; Dyson et al., 2010; Dyson \& Strachan, 2000, 2004). Students motivated and encouraged each other to learn, accepting and supporting the idea that all students had a role to play in each other's learning. Significantly, this involved the inclusion of those with learning difficulties and those who often disengage themselves from lessons, such as disaffected girls (Andre et al., 2013, 2011; Bayraktar, 2011; Casey, 2013; Casey et al., 2009; Goodyear et al., 2012, 2013; Dyson, 2002, 2001; Dyson \& Strachan, 2000, 2004; O’Leary \& Griggs, 2010; Polvi \& Telama, 2000).

\section{Affective learning}

While academic and social learning were the most frequently reported learning outcomes, affective learning was rarely considered. Drawing on the work of Bailey et al. (2010), Kretchmer (2005), and Pope (2005) we suggest that affective learning in physical education and sport pedagogy is largely associated with psychological components of selfconfidence, self-esteem, motivation, and self-worth. Yet within models-based practice (Metzler, 2011) and in the studies reporting on the learning outcomes of Cooperative Learning in this paper, affective learning was used an umbrella term to describe both social and psychological aspects of learning. For example, Dyson (2002) argued that affective learning developed but in positioning this form of learning he drew mainly on social learning outcomes, such as cooperation and students ability to encourage each other. 
A further explanation for the lack of empirical research on the affective domain is that the purpose of most studies was to explore how students improved their performance, developed their cognitive understanding, and enhanced their social learning. Affective learning was rarely noted as a prominent feature of investigation. These limited accounts of the 'psychological' aspect of learning, and the perhaps misleading evidence exploring the psychological aspects of learning, seem to highlight Pope’s (2005) argument that affective learning is somewhat challenging to define due to its subjective and personal nature.

Nevertheless, while there was limited evidence reporting on the affective domain many of the studies did suggest that students increased in self-confidence, self-esteem, and motivation (c.f. Goodyear \& Casey, 2013; Goodyear et al., 2012). In their work exploring girls’ engagement in physical education Goodyear et al. (2012) made an attempt to separate the social and affective domains by suggesting that social and cognitive learning had an influence on students motivation and engagement. This study showed that girls who had previously disengage from traditional forms of physical education became more motivated to learn when they were afforded the opportunity to participate in promotive face-to-face interactions and when they could analyze, evaluate, and provide feedback on their peers' performance. Similarly, those students that were described as often being enthusiastic learners in traditional lessons became more motivated during Cooperative Learning when they could lead their team through learning tasks and create physical movement tasks to develop their team’s game performance. Consequently, Goodyear et al. (2012) provide an example as to how the social learning domain differs to the affective domain and they show how social and affective learning might also be seen on par with one another. However, on a cautionary note, this example, coupled with a number of other statements pertaining to selfconfidence, self-esteem, or motivation rely on teachers' and students' subjective 
interpretation of learning and improvements (Dyson et al., 2010; Dyson \& Strachan, 2000; 2004; Goudas \& Magotsiou, 2009; Polvi \& Telama, 2000; Lafont et al., 2007).

Exceptions to the somewhat subjective interpretations of affective learning came from the work of Cohen and Zach (2012) and Wang (2012). Cohen and Zach (2012) used the 'physical education teaching self efficacy questionnaire' as a measure of determining preservice teachers' self-efficacy. These authors suggested that self-efficacy was in fact higher when the pre-service teacher used a 'traditional approach'. Similar to Casey's reports on teachers' use of pedagogical models (Casey, 2014), and more specifically teachers' use of Cooperative Learning (c.f. Casey and Dyson, 2009; Casey et al., 2009), Cohen and Zach (2012) suggested that pre-service teachers had a lower self-efficacy since they were using Cooperative Learning for the first time. Indeed, pre-service and in-service teachers often feel out of their comfort zone when learning to teach in a new way (Casey, 2014) where the lower self-efficacy can be associated with teacher learning to teach in a new way.

Moving beyond the exploration of the affective domain in relation to pre-service teachers, Wang (2012) used the 'achievement motivation scale' to explore the affective learning of students in higher education as learners within Cooperative Learning. Wang's (2012) study showed that students who experienced Cooperative Learning had greater achievement motivation. Wang (2012) suggested that the increase in achievement motivation during Cooperative Learning could be interrelated with learners’ higher self-efficacy, successful experiences, group goals, and positive peer relations.

In taking Wang's (2012) increase in achievement motivation a step further, and by drawing on Deci and Ryan (2000), it seems reasonable to suggest that there was an increase in achievement motivation since students were, broadly speaking, intrinsically and extrinsically motivated. While this is a conceptual link, and it is important to note that Wang's (2012) study did not detail the elements or the structure of Cooperative Learning, this 
finding combines with both Johnson and Johnson’s (2009) and Slavin’s (1996) perspectives on Cooperative Learning. Indeed, Johnson and Johnson (2009), whose work is very much based on Deutsch's (1949) social interdependence theory, suggest that increased effort to achieve is associated with interrelated learning goals between group members. These goals provide learners within an internal drive to help their peers to learn, and subsequently, their team to achieve. In contrast, Slavin (1996) argued that Cooperative Learning methods that rely solely on student interaction could not predict higher student motivation. Slavin (1990) claims that in order to for students to be motivated and engaged within the learning tasks individuals and team members should be given rewards for their learning. Therefore, Wang's (2012) study is the first within physical education to provide an indication that both Johnson and Johnson’s (2009) and Slavin’s (1996) perspectives need to be considered with regard to the affective domain. The findings from Wang (2012) suggest that positively interrelated goals and individual/team rewards can promote students' motivation by satisfying learners’ needs, that is, autonomy, competence and relatedness (c.f. Deci \& Reyan, 2000).

This section has shown there is limited evidence and empirical examples of affective learning within Cooperative Learning in physical education. However, the emerging findings do suggest Cooperative Learning can support this learning domain and the findings warrant further exploration of affective learning in K-12 education.

\section{Discussion}

We set out from the start of this paper to answer the methodological question "how has the empirical research in the use of Cooperative Learning in physical education reported on the achievement of learning in the physical, cognitive, social and affective domains (or their equivalents)?” The simple answer is that the empirical research shows that Cooperative Learning reports on the achievement of learning in all four learning domains in physical education. It reports predominantly, and most robustly, on physical, cognitive, and social 
learning while offering a succession of anecdotal examples that indicate that the model facilitates learning in the affective domain.

At a deeper and more critical level, this review of literature suggests that were Cooperative Learning receiving an interim school report it would be told that while it had enjoyed a promising start in physical education it still had much to prove. Although most of the studies did suggest that learning in each domain was strengthened there were certainly limitations in the approach of each study. Most particularly there was the brevity of many interventions (less than six weeks in some cases) and the lack of a report on the researchers' attempts to maintain fidelity to the model. As Casey (2014) surmised, we would argue that while we know 'it works', we do not know (a) to what degree it works over time, and (b) what the full potential of the model is when fidelity is maintained.

Kirk (2012, 2013) has positioned models as the medium ( 10 years) and longer-term ( 20 years) future of physical education and yet we know little about the effects of the longitudinal use of the model. Casey (2013) and Dyson and Strachan (2004, 2000) respectively are the only researchers to publish studies that report on sequential learning and learning over time. Through these studies we begin to understand that student learning in the four domains was advanced and deepened, but again this only explored learning over a two year period; nothing near the extent of the mid or even longer term future that Kirk has talked about. As Rovegno (2008, p. 92) suggests, “we are only beginning to unpack the complexity of these learning environments”, and therefore it seems imperative that we investigate the longitudinal use of pedagogical models and learn what happens when models are used over extended periods of time.

In light of these discussions, important questions are raised about the 'real-life' impact of short units of Cooperative Learning (i.e. 10 lessons or less) and the potential of the model if longer interventions were to become the norm (as in the instances of Casey and 
Dyson and Strachan respectively (see above)). As these authors reported the biggest impact on learning occurred when students had learnt to learn through Cooperative Learning, it serves the field to know more about the learning outcomes that result from sustained use of the model. Furthermore, while the affective domain may have received a lack of attention due to the impersonal and subjective nature of this form of learning (Pope, 2005), we would also argue that learning in this domain takes time to develop. This claim has plausibility when you consider that most studies reviewed reported that the three other learning domains were developed: even in shorter units (lasting 12-14 lessons or less) and when they were not the prominent feature of investigation.

In considering 'how' we might explore the affective domain, methods that did provide an understanding of affective learning were both interviews and standardized measures, such as the physical education teaching efficacy questionnaire (Cohen \& Zach, 2012).

Subsequently, we argue that understanding affective learning is both possible and desirable and we call for further research that explores learning within this domain over time. Yet in reiterating Bailey et al. (2009), in order to define and understand the authentic impact of this learning domain, it also seems reasonable to suggest that further research into affective learning in physical education more generally is also required, particularly when valuing the physically active life and motivation are the subject's raison d'etre (Kirk, 2012).

In further considering future research agendas, we argue that research should further explore the impact of Cooperative Learning structures (i.e. Jigsaw, learning teams, pairscheck-perform c.f. Dyson \& Grineski, 2001)) on learning in the four domains. Certainly, one of the advantages of Cooperative Learning is that there are hundreds of structures that allow teachers to vary the way students access academic content and interact with one another in order to learn (Goodyear, 2013; Kagan \& Kagan, 2009). Yet while Cooperative Learning affords such variability, this review has shown that the structure of learning teams (Dyson \& 
Grineski, 2001) has been the dominant structure applied and we know little about how other structures impact students’ learning.

Exploring the Cooperative Learning structures becomes even more significant when we consider that physical education has followed Johnson and Johnson’s conceptual approach (Goodyear, 2013). Indeed, learning teams has great synergy with Johnson and Johnson's (2009) structure learning together. As a result the principles of team rewards, the use of multiple structures in lessons and, group accountability (principles respectively suggested by Slavin (1995, 1996), Kagan and Kagan (2009), and Cohen (1994) to maximise achievement) have rarely been explored. By expanding the way Cooperative Learning is implemented through the use of structures such as Student Teams Achievement Division, Numbered Heads together, and Think-Share-Perform (that to some extent embody these somewhat unexplored principles in physical education (Kagan \& Kagan, 2009; Slavin, 1996)), a further understanding around the essential elements or non-negotiable (c.f. Goodyear, 2013) features of Cooperative Learning that maximise learning in the four domains might be understood. Subsequently, we suggest a need for further research around the Cooperative Learning structures in physical education.

In concluding this review of literature we suggest that Cooperative Learning is a model that can contribute to achieving the legitimate learning outcomes of physical education (Bailey et al., 2009; Kirk, 2012, 2013). However, a key limitation in our understanding of the model is that we know little about what happens beyond the initial unit of work (Casey, 2011; Goodyear \& Casey, 2013). Subsequently, in order to understand Cooperative Learning as a pedagogical model, further research is required on students’ learning, teachers' use of a model, the Cooperative Learning structures, and how the school contextual factors constrain or facilitate teachers' use of a model "beyond the honeymoon of pedagogical renovation" (Goodyear \& Casey, 2013, p. 1). 


\section{References}

André, A., Deneuve, P., \& Louvet, B. (2011). Cooperative learning in physical education and acceptance of students with learning disabilities. Journal of Applied Sport Psychology, 23(4), 474-485.

André, A., Louvet, B., \& Deneuve, P. (2013). Cooperative group, risk-taking and inclusion of pupils with learning disabilities in physical education. British Educational Research Journal, 39(4), 677-693.

Aronson, E., Blaney, N., Stephan, C., Sikes, J., \& Snapp, M. (1978). The Jigsaw classroom. Beverley Hills, CA: Sage

Bähr, I., \& Wibowo, J. (2012). Teacher action in the Cooperative Learning model in the physical education classroom. In B. Dyson \& A. Casey (Eds.), Cooperative Learning in physical education: A research-based approach (pp. 27-41). London: Routledge.

Bailey, R., Armour, K., Kirk, D., Jess, M., Pickup, I., \& Sandford, R. (2009). The educational benefits claimed for physical education and school sport: An academic review. Research Papers in Education, 24(1), 1-27.

Barr, H., Hammick, M., Koppel, I., \& Reeves, S. (1999). Evaluating interprofessional education: Two systematic reviews for health and social care. British Educational Research Journal, 25(4), 533-544.

Barrett, T. (2005). Effects of cooperative learning on the performance of sixth-grade physical education students. Journal of Teaching in Physical Education, 24 (1), 88-102.

Bayraktar, G. (2011). The effect of cooperative learning on students' approach to general gymnastics course and academic achievements. Educational Research and Reviews, 6(1), 62-71.

Boaz, A., Ashby, D., \& Young, K. (2002). Systematic reviews: What have they got to offer evidence based policy and practice? ESRC UK Centre for Evidence Based Policy and Practice, Queen Mary University of London.

Casey, A. (2014). Models-based practice: great white hope or white elephant?. Physical Education and Sport Pedagogy, 19(1), 18-34.

Casey, A. (2013). Seeing the trees not just the wood”: Steps and not just journeys in teacher action research', Educational Action Research, 21(2), 147-163.

Casey, A. (2011, June). A review of literature of teachers' use of models-based practice: 1996 to the present. Paper Presented at the Association Internationale des Ecoles Superieures d'Education Physique (International Association for Physical Education in Higher Education) conference, University of Limerick, Ireland.

Casey, A. \& Dyson, B. (2012). Cooperative Learning in physical education. In B. Dyson \& A. Casey. (Eds.), Cooperative Learning in physical education: A research-based approach (pp. 166-175). London: Routledge.

Casey, A., \& Dyson, B. (2009). The implementation of models-based practice in physical education through action research. European Physical Education Review, 15(2), 175199.

Casey, A., Dyson, B., \& Campbell, A. (2009). Action research in physical education: Focusing beyond myself through cooperative learning. Educational Action Research, 17 (3), 407-423.

Cohen, R., \& Zach, S. (2012). Building pre-service teaching efficacy: a comparison of instructional models. Physical Education and Sport Pedagogy, i First Article.

Darnis, F., \& Lafont, L. (2013). Cooperative learning and dyadic interactions: two modes of knowledge construction in socio-constructivist settings for team-sport teaching. Physical Education and Sport Pedagogy, I First Article. 
Deci, E.L., \& Ryan, R.M. (2000). The "what" and "why” of goal pursuits: human needs and self-determination of behavior. Psychological Inquiry, 11(4), 227-268.

Denzin, N.K., \& Lincoln, Y.S. (1994). Handbook of Qualitative Research. Thousand Oaks, CA: Sage.

Deutsch, M. (1949). A theory of cooperation and competition. Human Relations, 2, 129-151

Dowler, W. (2012). Cooperative Learning and interactions in inclusive secondary school physical education classes in Australia. In B. Dyson \& A. Casey (Eds.), Cooperative Learning in physical education: A research-based approach (pp. 150-165). London: Routledge.

Dyson, B. (2002). The implementation of cooperative learning in an elementary physical education program. Journal of Teaching in Physical Education, 22(1), 69-85.

Dyson, B. (2001). Cooperative learning in an elementary physical education program. Journal of Teaching in Physical Education, 20(3), 264-281.

Dyson, B., \& Casey, A. (2012). Cooperative Learning in physical education: A researchbased approach. London: Routledge.

Dyson, B., Griffin, L.L., \& Hastie, P. (2004). Sport education, tactical games, and cooperative learning: Theoretical and pedagogical considerations. Quest, 56(2), 226-240.

Dyson, B., \& Grineski, S. (2001). Using cooperative learning structures in physical education. The Journal of Physical Education, Recreation and Dance, 72(2), 28-31.

Dyson, B., Linehan, N.R., \& Hastie, P.A. (2010). The ecology of cooperative learning in elementary physical education classes. Journal of Teaching in Physical Education, 29 (2), 113-130.

Dyson, B., \& Rubin, A. (2003). Implementing cooperative learning in elementary physical education. The Journal of Physical Education, Recreation \& Dance, 74(1), 48-55.

Dyson, B., \& Strachan, K.W. (2000). Cooperative learning in a high school physical education program. Waikato Journal of Education, 6, 19-37.

Dyson, B., \& Strachan, K. (2004). The ecology of cooperative learning in a high school physical education program. Waikato Journal of Education, 10, 117-139.

Ennis, C. D. (1999). Creating a culturally relevant curriculum for disengaged girls. Sport, Education \& Society, 4, 31-49.

Goodyear, V.A. (2013). Participatory action research: challenging the dominant practice architectures of physical education. Unpublished Doctoral Thesis, University of Bedfordshire.

Goodyear, V.A., \& Casey, A. (2013). Innovation with change: developing a community of practice to help teachers move beyond the 'honeymoon' of pedagogical renovation, Physical Education and Sport Pedagogy, DOI:10.1080/17408989.2013.817012

Goodyear, V.A., Casey, A., \& Kirk, D. (2013). Using flip cameras as a pedagogic device to explore girls' (dis)engagement in physical education. Active and Healthy Magazine: Australian Council Health, Physical Education and Recreation, 20(3/4), 5-9

Goodyear, V.A., Casey, A., \& Kirk, D. (2012). Hiding behind the camera: social learning within the Cooperative Learning model to engage girls in physical education. Sport, Education \& Society, i First article.

Gossett, M., \& Fischer, O. (2005). Bringing together critical thinking and cooperative learning between two schools. Strategies: A Journal for Physical and Sport Educators, 19(2), 27-30.

Goudas, M., \& Magotsiou, E. (2009). The effects of a cooperative physical education program on students' social skills. Journal of Applied Sport Psychology, 21(3), 356-364.

Grineski, S. (1996). Cooperative learning in physical education. Champaign, IL: Human Kinetics. 
Haerens, L., Kirk, D., Cardon, G., \& De Bourdeaudhuij, I. (2011). Toward the development of a pedagogical model for health-based physical education. Quest, 63(3), 321-338.

Hastie, P., \& Casey, A. (2010). Using the jigsaw classroom to facilitate studentdesigned games. Physical Education Matters, 5(1), 15-16.

Harvey, S., \& Jarrett, K. (2013). A review of the game centered approaches to teaching and coaching literature since 2006. Physical Education and Sport Pedagogy, I first article

Hastie, P.A., de Ojeda, D.M., \& Luquin, A.C. (2011). A review of research on sport education: 2004 to the present. Physical Education \& Sport Pedagogy, 16(2), 103-132.

Hilke, E.V. (1990). Cooperative learning. Bloomington, Indiana: Phi Delta Kappa Educational Foundation.

Jewett, A. E., \& Bain, L.L. (1985). The curriculum process in Physical Education. Dubeque, Iowa: Wm. C. Brown.

Johnson, D. W., \& Johnson, R. T. (1974). Instructional Goal Structure: Cooperative, Competitive, or Individualistic. Review of Educational Research, 44(2), 213-240 .

Johnson, D., \& Johnson, F. (2009). Joining together: group theory and group skills. Upper Saddle River: N.J. Pearson.

Johnson, R.T., Bjorkland, R., \& Krotee, M.L. (1984). The effects of cooperative, competitive and individualistic student interaction patterns on the achievement and attitudes of students learning the golf skill of putting. Research Quarterly for Exercise and Sport, 35(2), 129-134.

Johnson, D.W., Johnson, R.T., \& Stanne, M.B. (2000). Cooperative learning methods: A meta-analysis. Available at: http://www.tablelearning.com/uploads/File/EXHIBIT-B.pdf (Accessed: 3rd May 2013).

Johnson, D. W., Maruyama, G., Johnson, R. T., Nelson, D., \& Skon, L. (1981). Effects of cooperative, competitive and individualistic goal structures on achievement: A metaanalysis. Psychological Bulletin, 89, 47-62.

Kagan, S., \& Kagan, M. (2009) Kagan cooperative learning. San Clemente, CA: Kagan Publishing.

Kirk, D. (2012) 'What is the future for physical education in the 21st century?', In S. Capel and M. Whitehead (Eds.), Debates in physical education (pp. 220-231) London: Routledge..

Kirk, D. (2013). Educational Value and Models-Based Practice in Physical Education. Educational Theory and Philosophy, i First Article

Kitchenham, B. (2004). Procedures for performing systematic reviews (No. 0400011T.1). Keele, UK: Software Engineering Group, Department of Computer Science, Keele University.

Kyndt, E., Raes, E., Lismont, B., Timmers, F., Cascallar, E., \& Dochy, F. (2013). A metaanalysis of the effects of face-to-face cooperative learning. Do recent studies falsify or verify earlier findings?. Educational Research Review, 10, 133-149.

Lafont, L. (2012). Cooperative Learning and tutoring in sports and physical activities. In B. Dyson \& A. Casey (Eds.), Cooperative Learning in physical education: A researchbased approach (pp. 136-149). London: Routledge..

Lafont, L., Proeres, M., \& Vallet, C. (2007). Cooperative group learning in a team game: Role of verbal exchanges among peers. Social Psychology of Education, 10(1), 93-113.

Lee, R.M., \& Fielding, N.G. (2009). Tools for quantitative data analysis. In M. Hardy \& A. Bryman (Eds.), The Handbook of Data Analysis (pp. 529-546). London: Sage.

Lieberman, A., \& Pointer-Mace, D. (2008). Teacher learning: The key to educational reform. Journal of Teacher Education, 59(3), 226-234.

Lincoln, Y.S., \& Guba, E.G. (1985). Naturalistic Inquiry. London: Sage 
Metzler, M. (2011). Instructional models for physical education. $3^{\text {rd }}$ edn. Arizona: Holcomb Hathway.

O’Leary, N., \& Griggs, G. (2010). Researching the pieces of the puzzle: the use of a jigsaw learning approach in the delivery of undergraduate gymnastics. Journal of Further and Higher Education, 34(1), 73-81.

O'Sullivan, M. (2013). New directions, new questions: Relationships between curriculum, pedagogy, and assessment in physical education. Sport, Education \& Society, 18(1), 1-5.

Pawson, R., Greenhalgh, T., Harvey, G., \& Walshe, K. (2004). Realist synthesis: An introduction. Manchester: ESRC Research Methods Programme, University of Manchester.

Polvi, S., \& Telama, R. (2000). The use of cooperative learning as a social enhancer in physical education. Scandinavian Journal of Educational Research, 44(1), 105-115.

Pope, S. (2005). Once more with feeling: Affect and playing with the TGfU model. Physical Education and Sport Pedagog, 10(3), 3: 271-86.

Potter, J. (2009). Discourse analysis. In M. Hardy \& A. Bryman (Eds.), The Handbook of Data Analysis (pp. 607-624). London: Sage.

Rovegno, I. (2008). Learning and instruction in social, cultural environments: Promising research agendas. Quest, 60(1), 84-104.

Shulruf, B. (2010). Do extra-curricular activities in schools improve educational outcomes? A critical review and meta-analysis of the literature. International Review of Education, 56, 591-612.

Slavin, R.E. (1996). Research for the future: Research on cooperative learning and achievement: What we know, what we need to know. Contemporary Educational Psychology, 21, 43-69.

Slavin, R.E. (1995). Cooperative learning. 2nd edn. Needham Heights, Massachusetts: Allyn and Bacon.

Slavin, R.E. (1990). Cooperative Learning: theory, research, and practice. Boston: Allyn and Bacon.

Slavin, R.E. (1983). When does cooperative learning increase student achievement?', Bulletin, 94, 429-445.

Smith, A., \& Parr, M. (2007). Young people's views on the nature and purposes of physical education: a sociological analysis. Sport, Education and Society, 12(1), 37-58.

Stanne, M., Johnson, D. W., \& Johnson, R. (1999). Social interdependence and motor performance: A meta-analysis. Psychological Bulletin, 125(1), 133-154.

Velázquez-Callado, C. (2012). Using cooperative learning to teach jump rope to elementary students. Physical Education Matters, 7(3) 38-41.

Wang, M. (2012). Effects of cooperative learning on achievement motivation of female university students. Asian Social Science, 8(15), 108-114.

Ward, P., \& Lee, M. (2005). Peer-assisted learning in physical education: A review of theory and research. Journal of Teaching in Physical Education, 24(3), 205- 225.

Yoder, L.J. (1993). Cooperative learning and dance education. Journal of Physical Education, Recreation and Dance (JOPERD), May-June, 47-56.

Zhu, X., Ennis, C.D., \& Chen, A. (2011). Implementation challenges for a constructivist physical education curriculum. Physical Education and Sport Pedagogy, 16(1), 83-99. 


\begin{tabular}{|c|c|c|}
\hline \multicolumn{3}{|c|}{ Manuscript Quest 2014-0017 } \\
\hline \multicolumn{3}{|c|}{ Reviewer 1} \\
\hline Comment & Author Response & Example Text \\
\hline $\begin{array}{l}\text { I would like to commend } \\
\text { the authors on an } \\
\text { interesting review of the } \\
\text { literature on Cooperative } \\
\text { Learning within Physical } \\
\text { Education. The manuscript } \\
\text { certainly raises some } \\
\text { important points regarding } \\
\text { what we know about the } \\
\text { use of Cooperative } \\
\text { Learning in Physical } \\
\text { Education and provides } \\
\text { insight into future } \\
\text { direction for research in } \\
\text { this area. My comments } \\
\text { below serve to guide the } \\
\text { authors in possible ways in } \\
\text { which the manuscript can } \\
\text { be further improved. }\end{array}$ & $\begin{array}{l}\text { Thank you for your kind } \\
\text { words, We are very } \\
\text { grateful of your guiding } \\
\text { comments and feel that } \\
\text { your review has allowed } \\
\text { us to further develop the } \\
\text { paper. }\end{array}$ & \\
\hline $\begin{array}{l}\text { The author's move } \\
\text { between 1st and 3rd points } \\
\text { at different points } \\
\text { throughout the manuscript } \\
\text { and I would suggest } \\
\text { picking one and sticking } \\
\text { with it. }\end{array}$ & $\begin{array}{l}\text { We have interpreted this } \\
\text { comment as a shift in } \\
\text { argument from } 1^{\text {st }} \text { and } 3^{\text {rd }} \\
\text { person. Subsequently we } \\
\text { have maintained a } 1^{\text {st }} \\
\text { person argument and } \\
\text { modified any third person } \\
\text { statements. These were } \\
\text { noted to mainly occur in } \\
\text { the methods section and } \\
\text { have been changed from } \\
\text { 'the authors' to 'we' were } \\
\text { possible. }\end{array}$ & \\
\hline $\begin{array}{l}\text { Overall you have built a } \\
\text { good case for the need for } \\
\text { this review by linking it to } \\
\text { the future of physical } \\
\text { education in model-based } \\
\text { practice and achieving the } \\
\text { four learning domains in } \\
\text { physical education. } \\
\text { However, I feel that the } \\
\text { last paragraph of this } \\
\text { section (lines 124-138) } \\
\text { needs to provide a stronger } \\
\text { rationale for review based } \\
\text { on the case you have made }\end{array}$ & $\begin{array}{l}\text { We have now modified } \\
\text { this section on page } 6 \text { Line } \\
\text { 136-144 to draw the } \\
\text { argument back to our } \\
\text { original position at the } \\
\text { start of the paper } \\
\text { surrounding the } \\
\text { educational benefits of } \\
\text { physical education and the } \\
\text { models-based approach as } \\
\text { a future pedagogical } \\
\text { practice }\end{array}$ & $\begin{array}{l}\text { In order to legitimize } \\
\text { Cooperative Learning as a } \\
\text { current and future pedagogical } \\
\text { practice, we need to move } \\
\text { beyond the notion that } \\
\text { Cooperative Learning 'works' } \\
\text { and start to think of the future } \\
\text { directions for research in this } \\
\text { area (Casey, 2014). Certainly } \\
\text { we need a comprehensive } \\
\text { understanding of if and how } \\
\text { Cooperative Learning provides } \\
\text { the right pedagogical } \\
\text { circumstances for achieving the } \\
\text { educational beneficial learning } \\
\text { outcomes of physical education. } \\
\text { In doing so, and as this review }\end{array}$ \\
\hline
\end{tabular}




\begin{tabular}{|c|c|c|}
\hline $\begin{array}{l}\text { leading up to this. I } \\
\text { suggest really selling the } \\
\text { need and importance of } \\
\text { this review in this } \\
\text { paragraph. }\end{array}$ & & $\begin{array}{l}\text { sets out to achieve, we can } \\
\text { begin to ascertain the } \\
\text { 'worthiness' of Cooperative } \\
\text { Learning within a models-based } \\
\text { approach and begin to } \\
\text { conceptualize directions for } \\
\text { future research that could } \\
\text { enhance and strengthen teaching } \\
\text { and learning in physical } \\
\text { education. }\end{array}$ \\
\hline $\begin{array}{l}\text { There seems to be an } \\
\text { overabundance of direct } \\
\text { quotes which reads a little } \\
\text { more like a dissertation } \\
\text { than a manuscript. I } \\
\text { suggest cutting down on } \\
\text { direct quotes and } \\
\text { paraphrasing the author's } \\
\text { points instead where } \\
\text { appropriate. }\end{array}$ & $\begin{array}{l}\text { Throughout the manuscript } \\
\text { we have reduced the } \\
\text { number of quotes that } \\
\text { were being used and } \\
\text { sought to paraphrase the } \\
\text { key findings }\end{array}$ & \\
\hline $\begin{array}{l}\text { Maybe this is just me, but } \\
\text { the use of hyphens instead } \\
\text { of commas or semi-colons } \\
\text { was distracting for me and } \\
\text { impacted the flow of my } \\
\text { reading. I suggest } \\
\text { changing this throughout } \\
\text { the document to help with } \\
\text { the readability of the } \\
\text { manuscript. However, I am } \\
\text { not wedded to this } \\
\text { suggestion and realize that } \\
\text { it may just be a quirk of } \\
\text { mine! }\end{array}$ & $\begin{array}{l}\text { The majority of hyphens } \\
\text { have been removed. } \\
\text { However, where we felt } \\
\text { that this kept with the } \\
\text { continuity of the sentence } \\
\text { these have remained } \\
\text { included. }\end{array}$ & \\
\hline \multicolumn{3}{|l|}{ Methodology } \\
\hline $\begin{array}{l}\text { Overall this section is very } \\
\text { detailed but reads a little } \\
\text { too much like a } \\
\text { dissertation. I suggest } \\
\text { pairing this section down } \\
\text { so that is it brief yet } \\
\text { detailed. At times it seems } \\
\text { as though you felt the need } \\
\text { to justify your decisions } \\
\text { rather than just reporting } \\
\text { on your methodology. I } \\
\text { suggest just reporting the } \\
\text { process you used to locate } \\
\text { the research to include in } \\
\text { the review (keywords, } \\
\text { databases etc), the }\end{array}$ & $\begin{array}{l}\text { This section has been } \\
\text { significantly reduced to } \\
\text { now focus on the specifics } \\
\text { of the methodological } \\
\text { approach }\end{array}$ & \\
\hline
\end{tabular}




\begin{tabular}{|c|c|c|}
\hline $\begin{array}{l}\text { inclusion and exclusion } \\
\text { criteria (this section needs } \\
\text { to be reduced. I suggest } \\
\text { not including examples of } \\
\text { papers that were included } \\
\text { and excluded but rather } \\
\text { how you decided what to } \\
\text { include and exclude), and } \\
\text { the process used to } \\
\text { synthesize the findings. }\end{array}$ & & \\
\hline $\begin{array}{l}\text { I also suggest including an } \\
\text { overall snapshot of the } \\
\text { types of research included. } \\
\text { It would be important to } \\
\text { know if the research was } \\
\text { all qualitative, all } \\
\text { quantitative, or a mix of } \\
\text { both, or if any single } \\
\text { subject research was } \\
\text { included. }\end{array}$ & $\begin{array}{l}\text { On page } 12 \text { line } 274-280 \\
\text { we have summarised the } \\
\text { types of research that were } \\
\text { included within this data } \\
\text { set. }\end{array}$ & $\begin{array}{l}\text { The mechanisms used to } \\
\text { make judgments about } \\
\text { student learning varied } \\
\text { between studies. Overall } \\
\text { there was a balance between } \\
\text { qualitative and quantitative } \\
\text { data procedures, yet most } \\
\text { judgments were made using } \\
\text { qualitative methods (14 } \\
\text { studies) rather than } \\
\text { quantitative (11 studies) or } \\
\text { mixed method designs (2 } \\
\text { studies). Furthermore, it was } \\
\text { only the quantitative studies } \\
\text { that compared student } \\
\text { learning to a control group } \\
\text { (11 studies). Subsequently, } \\
\text { over half of the judgments } \\
\text { about student learning were } \\
\text { not compared to other } \\
\text { learners practicing in a } \\
\text { different pedagogical } \\
\text { approach to Cooperative } \\
\text { Learning (16 studies). }\end{array}$ \\
\hline $\begin{array}{l}\text { This information would } \\
\text { help to situate the } \\
\text { synthesis of the findings. I } \\
\text { find the process you used } \\
\text { to synthesize the research } \\
\text { findings to be interesting } \\
\text { but am not sure of the fit } \\
\text { of these techniques to the } \\
\text { literature review process. I } \\
\text { would recommend } \\
\text { explaining your choice of } \\
\text { using these techniques as } \\
\text { they are not typical for a } \\
\text { review of literature } \\
\text { process. It seems to me } \\
\text { that you conducted a } \\
\text { thematic approach to } \\
\text { synthesizing the literature }\end{array}$ & $\begin{array}{l}\text { In re-reading and revising } \\
\text { the methodology section } \\
\text { we feel that this reflects } \\
\text { the processes that we } \\
\text { undertook. We hope that } \\
\text { the development of the } \\
\text { paper and the tightening of } \\
\text { this section will help you } \\
\text { to see what we did and } \\
\text { why. }\end{array}$ & \\
\hline
\end{tabular}




\begin{tabular}{|c|c|c|}
\hline $\begin{array}{l}\text { based on the outcomes of } \\
\text { the research on student } \\
\text { learning. }\end{array}$ & & \\
\hline Results & & \\
\hline $\begin{array}{l}\text { At the end of the } \\
\text { methodology section you } \\
\text { refer to the key findings as } \\
\text { themes but change this to } \\
\text { sub-themes later in the } \\
\text { section. I suggest keeping } \\
\text { it as themes throughout the } \\
\text { section rather than sub- } \\
\text { themes. }\end{array}$ & $\begin{array}{l}\text { Thank you for highlighting } \\
\text { this - the change in focus } \\
\text { from themes to sub-themes } \\
\text { has been modified and the } \\
\text { text now only reads } \\
\text { themes }\end{array}$ & \\
\hline $\begin{array}{l}\text { Within the themes it would } \\
\text { be helpful to understand if } \\
\text { the assertions you make } \\
\text { are based on qualitative, } \\
\text { quantitative or a mix of } \\
\text { both types of research. For } \\
\text { example, the first assertion } \\
\text { (lines 305-312) is that one } \\
\text { of the biggest reported } \\
\text { 'gains' has been in game } \\
\text { performance. Clarifying if } \\
\text { these gains were reported } \\
\text { in qualitative or } \\
\text { quantitative research (or a } \\
\text { mix of both) would be } \\
\text { helpful. }\end{array}$ & $\begin{array}{l}\text { This sentence has been } \\
\text { modified to highlight the } \\
\text { types of research that } \\
\text { informed this finding } \\
\text { We have undertaken this } \\
\text { process where possible but } \\
\text { on some occasions it was } \\
\text { beyond our capabilities } \\
\text { without restarting the } \\
\text { review from scratch. The } \\
\text { findings are inherent in the } \\
\text { papers but they also speak } \\
\text { of our understanding of the } \\
\text { field as a whole. We hope } \\
\text { this explanation serves to } \\
\text { explain why we have only } \\
\text { been partially successful in } \\
\text { addressing this concern. }\end{array}$ & $\begin{array}{l}\text { A central feature of } \\
\text { physical learning was } \\
\text { enhanced game } \\
\text { performance and } \\
\text { improvements to students' } \\
\text { motor skills. Quantitative } \\
\text { (3 studies), Qualitative (4 } \\
\text { studies) and, mixed } \\
\text { method designs (2 studies) } \\
\text { reported on the } \\
\text { improvements made by } \\
\text { students in this aspect of } \\
\text { physical education } \\
\text { (Barrett, 2005; Casey et } \\
\text { al., 2009; Darnis \& Lafont, } \\
\text { 2013; Dyson, 2002, 2001; } \\
\text { Dyson et al., 2010; Dyson } \\
\text { \& Strachan, 2000, 2004; } \\
\text { Lafont et al., 2007). }\end{array}$ \\
\hline $\begin{array}{l}\text { Academic Learning: This } \\
\text { theme needs further } \\
\text { elaboration and } \\
\text { development. There is } \\
\text { some important } \\
\text { information here that is } \\
\text { presented but not further } \\
\text { developed. Clearly if CL is } \\
\text { to promote student } \\
\text { learning in the four } \\
\text { domains, this section } \\
\text { needs to provide the } \\
\text { "evidence” that it is indeed } \\
\text { doing that and at present } \\
\text { falls a little short of that. } \\
\text { Further elaboration on how } \\
\text { CL promotes Academic } \\
\text { Learning and the }\end{array}$ & $\begin{array}{l}\text { Within this section we } \\
\text { have sought to expand on } \\
\text { the initial points raised. } \\
\text { We have highlighted what } \\
\text { features of physical and } \\
\text { cognitive learning the } \\
\text { studies in the review were } \\
\text { reporting to occur. } \\
\text { We have also included a } \\
\text { summary statement to } \\
\text { explicitly highlight the key } \\
\text { findings that can be drawn } \\
\text { from this theme. }\end{array}$ & $\begin{array}{l}\text { The text has been added to } \\
\text { various sections within this } \\
\text { theme and we have } \\
\text { highlighted the changes in } \\
\text { red }\end{array}$ \\
\hline
\end{tabular}




\begin{tabular}{|c|c|c|}
\hline $\begin{array}{l}\text { credibility of these claims } \\
\text { would be helpful here. }\end{array}$ & & \\
\hline $\begin{array}{l}\text { Social Learning: This } \\
\text { theme could benefit from } \\
\text { further development and } \\
\text { elaboration. For example, } \\
\text { there needs to be further } \\
\text { elaboration of the findings } \\
\text { around the development of } \\
\text { leadership skills (lines } \\
\text { 354-363). Alignment of } \\
\text { the quote to the points } \\
\text { made could be stronger. }\end{array}$ & $\begin{array}{l}\text { Within this section we } \\
\text { have sought to expand on } \\
\text { the initial points raised. } \\
\text { For example, we have } \\
\text { provided examples to the } \\
\text { differing forms of social } \\
\text { learning that were reported } \\
\text { to occur. } \\
\text { In reference to developing } \\
\text { leadership skills we have } \\
\text { sought to explicitly } \\
\text { highlight what the studies } \\
\text { were suggesting with } \\
\text { regard to leadership }\end{array}$ & $\begin{array}{l}\text { The text has been added to } \\
\text { various sections within this } \\
\text { theme and we have } \\
\text { highlighted the changes in } \\
\text { red } \\
\text { Example of leadership: One } \\
\text { of the reasons cited for } \\
\text { students' ability to cooperate } \\
\text { and show empathy and } \\
\text { respect for their teammates } \\
\text { was the developing } \\
\text { leadership skill set of the } \\
\text { students (Darnis \& Lafont, } \\
\text { 2013; Dyson, 2001; Dyson \& } \\
\text { Strachan, 2000). Specifically } \\
\text { enhanced leadership skills } \\
\text { were seen through students' } \\
\text { ability to guide their teams } \\
\text { through a process of learning, } \\
\text { their ability to take } \\
\text { responsibility for their own } \\
\text { and other individuals } \\
\text { learning, enhanced } \\
\text { communication skills, and in } \\
\text { particular, the ability to listen } \\
\text { and speak clearly (Casey, } \\
\text { 2004; Darnis \& Lafont, 2013; } \\
\text { Dyson, 2002, 2004; Dyson \& } \\
\text { Strachan, 2000; O’Leary \& } \\
\text { Griggs, 2010). }\end{array}$ \\
\hline $\begin{array}{l}\text { Team Participation: Again, } \\
\text { this theme needs further } \\
\text { elaboration and } \\
\text { development in places. } \\
\text { You make some important } \\
\text { and interesting assertions } \\
\text { which could benefit from } \\
\text { further development. }\end{array}$ & $\begin{array}{l}\text { We haven't elaborated on } \\
\text { this section as we felt this } \\
\text { was an extended finding of } \\
\text { social learning. However, } \\
\text { in addressing this point we } \\
\text { have included an } \\
\text { additional paragraph at the } \\
\text { end of the social learning } \\
\text { theme to show how these } \\
\text { two themes were inter- } \\
\text { linked with one another }\end{array}$ & $\begin{array}{l}\text { However, given the } \\
\text { prevalence of both Dyson } \\
\text { and Grineski’s (2001) } \\
\text { learning teams structure (it } \\
\text { featured in eleven out of the } \\
\text { twenty-seven studies) and } \\
\text { Aronson, Blaney, Stephan, } \\
\text { Sikes, and Snapp (1978) } \\
\text { Jigsaw Classroom structure } \\
\text { (featuring in four studies) } \\
\text { coupled with the clear } \\
\text { emphasis on games lessons } \\
\text { (fourteen out of the twenty- } \\
\text { seven studies used games as } \\
\text { their context of choice), it is } \\
\text { unsurprising to discover that } \\
\text { team participation made up } \\
\text { the majority of the reports } \\
\text { about social learning. }\end{array}$ \\
\hline $\begin{array}{l}\text { I would recommend } \\
\text { adding a summary }\end{array}$ & $\begin{array}{l}\text { In the process of } \\
\text { elaborating on the previous }\end{array}$ & \\
\hline
\end{tabular}




\begin{tabular}{|c|c|c|}
\hline $\begin{array}{l}\text { paragraph after the } \\
\text { affective learning theme to } \\
\text { summarize the findings } \\
\text { from the review to help } \\
\text { with a transition to the } \\
\text { discussion section. What } \\
\text { are the take home } \\
\text { messages you want the } \\
\text { reader to know based on } \\
\text { your review? }\end{array}$ & $\begin{array}{l}\text { themes and in order to } \\
\text { support coherence with the } \\
\text { approach we have } \\
\text { expanded on the original } \\
\text { points raised within this } \\
\text { theme and also included a } \\
\text { summary paragraph to } \\
\text { highlight the key points } \\
\text { before moving into the } \\
\text { conclusion. }\end{array}$ & \\
\hline Discussion: & & \\
\hline $\begin{array}{l}\text { On line } 442 \text { you introduce } \\
\text { that these findings also } \\
\text { come from physical } \\
\text { activity contexts but this is } \\
\text { not mentioned earlier. } \\
\text { Indeed the stated purpose } \\
\text { for the review is to } \\
\text { consider the use of CL in } \\
\text { physical education. Make } \\
\text { sure you are consistent } \\
\text { here. }\end{array}$ & $\begin{array}{l}\text { On lines 168-171 we have } \\
\text { sought to identify why } \\
\text { physical activity contexts } \\
\text { were included as terms } \\
\text { used in the review. } \\
\text { The term physical activity } \\
\text { has been removed from the } \\
\text { initial paragraph of the } \\
\text { discussion to keep the } \\
\text { focus being very much on } \\
\text { physical education }\end{array}$ & $\begin{array}{l}\text { Physical activity and } \\
\text { movement contexts were } \\
\text { selected as related terms to } \\
\text { further the scope of studies } \\
\text { found that reported on } \\
\text { Cooperative Learning in } \\
\text { physical education but to } \\
\text { also use physical activity } \\
\text { and other movement } \\
\text { related contexts to inform } \\
\text { physical education } \\
\text { literature. }\end{array}$ \\
\hline $\begin{array}{l}\text { Overall, the discussion } \\
\text { section is well written and } \\
\text { provides recommendations } \\
\text { for the next steps relative } \\
\text { to research on Cooperative } \\
\text { Learning in physical } \\
\text { education. }\end{array}$ & $\begin{array}{l}\text { Thank you very much for } \\
\text { these comments and for all } \\
\text { your advice on the paper }\end{array}$ & \\
\hline Specific comments & $\begin{array}{l}\text { Each of these comments } \\
\text { was address in the original } \\
\text { document before edits and } \\
\text { changes were made. We } \\
\text { are hopeful that we } \\
\text { addressed each of theme in } \\
\text { turn and thank you for } \\
\text { your diligence in this very } \\
\text { helpful process. }\end{array}$ & \\
\hline \multicolumn{3}{|c|}{ Reviewer 2} \\
\hline Comment & Author Response & Example Text \\
\hline $\begin{array}{l}\text { I read this paper with } \\
\text { interest and commend the } \\
\text { author(s) for undertaking } \\
\text { this review of the } \\
\text { literature. The author(s) } \\
\text { provide an accurate and } \\
\text { relevant review of the } \\
\text { literature on Cooperative } \\
\text { Learning in Physical }\end{array}$ & $\begin{array}{l}\text { Thank you for your } \\
\text { comments and support in } \\
\text { the review of this paper. }\end{array}$ & \\
\hline
\end{tabular}




\begin{tabular}{|c|c|c|}
\hline Education. & & \\
\hline $\begin{array}{l}\text { A greater understanding of } \\
\text { the different pedagogical } \\
\text { models is warranted as } \\
\text { represented by Kirk (2010) } \\
\text { and Metzler (2011). This } \\
\text { review appears appropriate } \\
\text { for publication in QUEST, } \\
\text { and could potentially make } \\
\text { fine contribution to the } \\
\text { existing literature base. }\end{array}$ & $\begin{array}{l}\text { Thanks again. We felt that } \\
\text { this was the case but it is } \\
\text { reassuring to get such } \\
\text { support from the wider } \\
\text { field. }\end{array}$ & \\
\hline $\begin{array}{l}\text { The major strength of the } \\
\text { manuscript is the depth of } \\
\text { understanding that the } \\
\text { author(s) present in this } \\
\text { manuscript on Cooperative } \\
\text { Learning in Physical } \\
\text { Education. The paper } \\
\text { demonstrates that they } \\
\text { have a far-reaching } \\
\text { knowledge of Cooperative } \\
\text { Learning as a pedagogical } \\
\text { practice. In addition, there } \\
\text { is a detailed and } \\
\text { comprehensive } \\
\text { explanation of the review } \\
\text { process. }\end{array}$ & $\begin{array}{l}\text { We have a lot of } \\
\text { experience with the model } \\
\text { but it is great to have this } \\
\text { vindicated in the review } \\
\text { process. Thank you. }\end{array}$ & \\
\hline $\begin{array}{l}\text { I applaud the author(s) } \\
\text { review of the Cooperative } \\
\text { Learning literature and } \\
\text { agree that further research } \\
\text { in warranted in what they } \\
\text { have defined as the } \\
\text { "affective” domain of } \\
\text { learning. Future research } \\
\text { on different pedagogical } \\
\text { practices is necessary and } \\
\text { would certainly contribute } \\
\text { to the field of research on } \\
\text { teaching and learning in } \\
\text { physical education. }\end{array}$ & $\begin{array}{l}\text { This was certainly the } \\
\text { most anecdotal of themes } \\
\text { to emerge from the review. }\end{array}$ & \\
\hline $\begin{array}{l}\text { Specific manuscript } \\
\text { comments: }\end{array}$ & & \\
\hline $\begin{array}{l}\text { The article is generally } \\
\text { well written but there are } \\
\text { some typos, for example, } \\
\text { in the abstract: }\end{array}$ & $\begin{array}{l}\text { We full acknowledge this } \\
\text { and the paper has been } \\
\text { tightly edited in an effort } \\
\text { to remove all of these } \\
\text { errors. }\end{array}$ & \\
\hline $\begin{array}{l}\text { p. } 1 \text { Line 12: "for" should } \\
\text { be "four" }\end{array}$ & This has been changed & \\
\hline
\end{tabular}




\begin{tabular}{|l|l|l|}
\hline $\begin{array}{l}\text { I did not copy-edit this } \\
\text { manuscript. I would }\end{array}$ & $\begin{array}{l}\text { We have paid very } \\
\text { particular attention to APA } \\
\text { in addition to other efforts } \\
\text { suggest that the author(s) } \\
\text { check and double check } \\
\text { that their paper adheres } \\
\text { closely to the APA format. }\end{array}$ & \\
\hline
\end{tabular}

